\title{
Chemoprevention with the metabolism modifying drugs dichloroacetate and metformin in Trp53+/- mice
}

\author{
AC Blackburn ${ }^{1 *}$, M Rooke 1 , Y Li', JE Dahlstrom², PG Board ${ }^{1}$
}

From Familial Aspects of Cancer 2011 Research and Practice: A combined meeting of kConFab, Australian Breast Cancer Family Study, Australian Colorectal Cancer Family Study, Australian Ovarian Cancer Study, Family Cancer Clinics of Australia and New Zealand and kConFab

Kingscliff, Australia. 23-26 August 2011

While genetic testing for familial cancer susceptibility factors has excelled in recent years, the prevention options for those carrying high risk alleles have not. Altered bioenergetics has now been acknowledged as an emerging hallmark of cancer, and is believed to be a critical characteristic acquired during tumorigenesis. Several very safe drugs are available that can modify bioenergetics. Dichloroacetate (DCA) inactivates pyruvate dehydrogenase kinase, resulting in activation of pyruvate dehydrogenase, reduced lactic acid production and increased mitochondrial activity. Metformin, a type 2 diabetes treatment which activates AMPK, thereby inhibiting mTOR, has unambiguously been demonstrated to reduce the risk of many cancer types in diabetics where insulin treatments do not. We have tested these drugs as chemopreventive agents against the mammary tumours that occur in the spontaneous BALB/c-Trp53+/- mouse tumour model.

In vitro studies on breast cancer cell lines indicate that DCA (1-5 mM), metformin (30-300 uM) or the combination of the two can significantly inhibit breast cancer cell growth over 4 days of treatment. These results support the possibility that DCA and metformin could prevent or delay breast cancer formation in BALB/c-Trp53 $+/$ - mice. To examine this, four groups of female BALB/ c-Trp53+/- mice were given distilled water $(\mathrm{n}=75)$, DCA $(1.5 \mathrm{~g} / \mathrm{L}$ in drinking water, $\sim 180 \mathrm{mg} / \mathrm{kg} /$ day, $\mathrm{n}=53)$, metformin $(0.25 \mathrm{~g} / \mathrm{L}$ in drinking water, $\sim 30 \mathrm{mg} / \mathrm{kg} /$ day, $\mathrm{n}=61)$ or DCA + metformin $(\mathrm{n}=51)$ from 8 weeks of age, and monitored for tumour development over 78 weeks. The overall tumour-free survival curves were not

${ }^{1}$ Molecular Genetics Group, John Curtin School of Medical Research, Australian National University, Canberra ACT 0200, Australia

Full list of author information is available at the end of the article significantly different (Kaplan-Meier analysis) between the treatment groups, suggesting that metformin does not reduce cancer risk in non-diabetics. However, the occurrence of mammary tumours in the four groups was altered. DCA reduced the number and increased the latency of mammary tumours $(20.8 \%$ of DCA treated mice with mean latency of 63.8 weeks compared to $28.0 \%$ of untreated mice with mean latency of 55.0 weeks), whereas metformin had no effect (26.2\% of mice, average latency 54.7 weeks). Examining the mammary tumour-free survival curves, DCA appeared to eliminate the early onset mammary tumours (latency $<52$ weeks, $\mathrm{p}=0.02$ ), while not affecting the occurrence of longer latency tumours. We are currently examining these tumours to identify characteristics that may explain this difference in sensitivity to DCA prevention. Contrasting with the in vitro cancer cell line result, the two drug combination had worse outcomes for tumour development, with $35.3 \%$ of mice developing mammary tumours with a decreased latency of 48.8 weeks $(\mathrm{p}<0.02$ compared to DCA alone). Preliminary western blotting results in MDA-MB-468 breast cancer cells found that DCA could block the activation of AMPK by metformin, indicating the potential for drug interactions. However, the outcomes of these drug interactions clearly differs in the fully transformed cancer cell (growth inhibition) compared to the preneoplastic cell (survival / growth advantage) and requires further investigation.

\section{Acknowledgements \\ This research was supported by NHMRC 366787 R.D. Wright Career Development Award, a National Breast Cancer Foundation Novel Concept} Award, and Cancer Australia PdCCRS. 


\section{Author details}

'Molecular Genetics Group, John Curtin School of Medical Research,

Australian National University, Canberra ACT 0200, Australia. ${ }^{2}$ Department of Anatomical Pathology, Canberra Hospital, Woden ACT 2606, Australia.

Published: 12 April 2012

doi:10.1186/1897-4287-10-S2-A62

Cite this article as: Blackburn et al:: Chemoprevention with the

metabolism modifying drugs dichloroacetate and metformin in Trp53

+/- mice. Hereditary Cancer in Clinical Practice 2012 10(Suppl 2):A62.

Submit your next manuscript to BioMed Central and take full advantage of:

- Convenient online submission

- Thorough peer review

- No space constraints or color figure charges

- Immediate publication on acceptance

- Inclusion in PubMed, CAS, Scopus and Google Scholar

- Research which is freely available for redistribution

Submit your manuscript at www.biomedcentral.com/submit
C Biomed Central 